\title{
The interaction of technological innovation and increases in productive capacity: Multiplication of loaves and fishes?
}

\author{
M. Guisado-González ${ }^{\mathrm{a}}$, M. Guisado-Tato ${ }^{\text {* }}$ and C. Ferro-Soto ${ }^{\mathrm{b}}$ \\ ${ }^{a}$ Universidad de Extremadura, Facultad de Estudios Empresariales y Turismo, Avda. de la Universidad, s/n, 10004 Cáceres, Spain \\ bUniversidad de Vigo, Facultad de Ciencias Económicas y Empresariales, Campus de Vigo, 36310 Vigo, Spain \\ *To whom all correspondence should be addressed \\ mguisado@uvigo.es
}

\begin{abstract}
Using the experience curve as a basis, this study analyses the influence of technology and increases to productive capacity on business productivity. In addition, we tested if both variables are complementary. The data used comes from the Business Environment and Enterprise Performance Survey (BEEPS), which refers to the Spanish economy in 2005. Our findings reveal that radical innovation activities and increases in productive capacity have a significant positive impact on business productivity. Incremental innovations do not have a significant influence, while the incorporation of technology through the purchase of machinery and equipment has a negative and significant influence. Finally, the conducted tests reveal that the different kinds of technologies analysed and increases in productive capacity are not complementary variables.
\end{abstract}

\section{Introduction}

Analyses of productivity determinants (either at the national, sectorial or company level) are usually performed using the classic Cobb-Douglas function, where physical capital and labour are considered as inputs. Other extended versions of this function have also been widely used, adding new variables, such as innovation, as additional inputs for the corresponding function. On this point, most empirical studies have found evidence that there is a positive and significant relationship between innovation and business productivity (Griliches, 1979, 1986; Mairesse \& Sassenou, 1991; Harhoff, 1998; Lotti \& Santarelli, 2001; Parisi et al., 2006; Jaumandreu, 2009; Casiman et al., 2010).

Since the mid-1960s, the Boston Consulting Group has conducted several empirical estimations to show that the unit costs of different homogeneous products declines alongside increases in their cumulative production (Boston Consulting Group 1972; Henderson 1980). Subsequently, Stobough and Townsend (1975) and Lieberman (1981) reaffirmed the evidence proving that accumulated production volume (experience) has a statistically significant influence on reductions in unit costs (productivity). Furthermore, Lieberman (1988) points out that, in certain circumstances, both technological and market leadership can bring about a significant competitive advantage and help companies to build entry barriers against potential competitors. This enables the possibility for companies to use the experience curve as a strategic tool, allowing them to contribute to decision-making so as to control the growth rate of rivals or finance increases in the corresponding technology gap. ${ }^{1}$ By using the experience curve, it is possible to understand the

${ }^{1}$ Cost leadership can be used to facilitate price reductions so as to gain market share, thereby causing - as the experience curve predicts - some rivals to have losses and others to reduce their benefits. With impact of technological innovation and sales growth on the productivity of firms, as well as the interaction between technology and growth in the generation of productivity.

In fact, the representative function of the experience curve is merely a variant of the classic Cobb-Douglas function, and is also linear in its logarithmic form (Day \& Montgomery, 1983).

The aim of this paper is to analyse if technological innovation and the growth rate of sales are variables that contribute to improving the productivity of Spanish companies. By using a basic experience curve, we can also look at the extent to which innovation and the growth rate of sales are complementary, substitutive or independent variables. Furthermore, our study is not only focused on manufacturing companies (as is the case with most studies), but also incorporates service companies. Finally, we note that almost all innovation studies in Spain use data from the Technological Innovation Panel (PITEC) or the Survey of Business Strategies (EEE). However, as a novelty, we use data from the Business Environment and Enterprise Performance Survey of the European Bank for Reconstruction and Development (EBRD) and the World Bank Group.

an identical pricing policy as one's rivals, it can also be used to obtain higher profits, and can therefore to make new technology investments. 


\section{Experience curve: Technology, cumulative production quantity and productivity}

The immediate antecedent of the experience curve is called the "learning curve". The ability to study productivity improvements through the use of the learning effect was first proposed in the early 1920 s, when it was noticed that the number of man-hours required to construct a plane decreased as the number of units built increased. Subsequently, the Boston Consulting Group (1972) noted that the cost reduction that occurred with the increases in cumulated production (experience) affected all components of the product's added value to a greater or lesser extent. This new understanding has led to the experience curve. The usual form of the experience curve is:

$$
C_{n}=C_{1} n^{-\lambda}
$$

where,

$\mathrm{C}_{\mathrm{n}}=$ cost of the nth unit

$\mathrm{C}_{1}=$ cost of the first unit

$\mathrm{n}=$ cumulative number of units

$\lambda=$ elasticity of unit costs with respect to cumulative volume.

To determine a representative equation of productivity related to technological innovation and growth experience, we assume a period in which "q" units of a product were manufactured. We consider the unit cost at the beginning of the period to be $C_{n}$ and at end of the period as $C_{n+q}$. We further assume that the forecasts of the experience curve are fulfilled so that $C_{n+q}<C_{n}$. Under these conditions, the growth rate of cumulative production $(\rho)$ and the rate of reduction of unit costs $(\mu)$ will be:

$$
\begin{aligned}
& \rho=\frac{(n+q)-n}{n}=\frac{q}{n} \\
& \mu=\frac{C_{n}-C_{n+q}}{C_{n}}
\end{aligned}
$$

By combining expressions (1), (2) and (3), we obtain:

$$
\mu=1-(1+\rho)^{-\lambda}
$$

Equation (4) reveals that there are two key sources of reducing unit costs: on the one hand, the growth rate of the experience $(\rho)$, which is dependent on increases in the company's market share; on the other hand, the level of technological innovation, as represented by the coefficient $\lambda$. This coefficient is related to the efficiency level of the technology used in the production process. When the technology is more efficient, the slope of the respective experience curve $(\lambda)$ is greater, and thus will also result in the largest reduction in unit costs for a given increase in cumulative production. As a result, each technology will lead to a specific experience curve.

Given that technology and cumulative production constitute two major drivers of business productivity, the question arises: Are both variables complementary, substitutive or independent with regards to productivity improvement? In this regard, there are indications, as there are studies empirical studies that emphasize that the most innovative and fastest growing companies often achieve better economic results (Petersen \& Ahmad, 2007; Birch, 1979).To answer this question, it is necessary to approach the concept of complementarity and the possibility of its empirical evaluation.

\section{On approaches to complementarity}

The word "complementarity" has been used with some profusion in many scientific disciplines, but almost always with little conceptual rigour. The word is often used to implicitly suggest that two activities are complementary, such as when the simultaneous action of the two enables them to complete or perfect something. Consequently, the determination of the existence of complementarity is always ex post.

In the economic sphere, Edgeworth $(1881,1925)$ was the first economist to introduce a utility function in his analyses of the economic equilibrium of complementary goods, thereby improving the first contributions from Cournot (1838) and Bertrand (1883).

The term first started being used in the field of strategy and organizational analysis throughout 1960s and 1970s, although references were generally vague and imprecise (e.g. Rothwell et al., 1974; Rothwell, 1975).

However, the term began to be used more frequently in the 1980s in the field of organizational design literature (Miller \& Friesen, 1984; Miller, 1986). In this case, the word "complementary" is used as synonym of fit or congruence between strategy, organizational structure and various contextual factors, implying that when such congruence takes place, companies can attain an edge over those firms who lack it.

From the so-called "resource-based view of the firm" it can be noted that the construction of competitive advantage depends primarily on a combination of unique heterogeneous resources (Wernerfelt, 1984; Barney, 1991; Conner, 1991; Peteraf, 1993). This new approach has prompted researchers to analyse so-called complementary assets (e.g. Powell \& Dent-Micallef, 1997; Somaya, Williamson \& Zhang, 2007; Adegbesan, 2009), so as to try to unravel the secrets behind the generation of competitive advantages.

Moreover, in the specific field of innovation strategies, contributions from Rosenberg (1990), Freeman (1991) and Cohen and Levinthal $(1989,1990)$ indicate the existence of clear evidence of complementarity between strategies of internal knowledge generation and external knowledge acquisition.

Although many authors in the 1990s sensed the existence of complementarities between different economic activities, 
none of them measured it empirically and directly, probably because no one had noticed the mathematical model created by Topkis (1978) which established the conditions that allowed its empirical evaluation.

In economics, it is common to resort to the use of convex and concave functions, due to the fact they are continuous and therefore differentiable, allowing an accurate analysis of the changes that occur in the parameters under study. However, there are economic phenomena that cannot be represented precisely with these kinds of functions. In these cases - where the objective function is not concave or convex - it is not appropriate to use differential techniques to study the effects of changing parameters. Instead it is necessary to introduce "very restrictive assumptions" whose practical applicability is meagre.

However, Topkis (1978), using so-called order relations $(\geq)$ and without any topological properties (compactness, continuity, etc.), has developed the so-called lattice-theoretic, within which are defined the so-called supermodular functions. This class of functions allows the user to formalize the conditions of complementarity between groups of variables in a precise manner.

Subsequently, some authors applied the lattice-theoretic to economic analysis. In an analysis of the so-called general economy, Vives (1990) considered the Nash equilibrium in the context of complementarities of a strategic nature. Milgrom and Roberts (1990), meanwhile, introduced supermodular functions to strategic decision-making in the context of a multi-product company with a flexible manufacturing process.

It is beyond the scope of this study to present the mathematical formalization of supermodular functions. However, following Milgrom and Roberts (1990) and Cassiman and Veugelers (2006), we can present their most important conclusions regarding the evaluation of the complementarity of two business policies $\left(\mathrm{P}_{1}\right.$ and $\left.\mathrm{P}_{2}\right)$. If we assume that each policy can be performed $\left(\mathrm{P}_{\mathrm{i}}=1\right)$ or not performed $\left(\mathrm{P}_{\mathrm{i}}=0\right)$ by the company and $\mathrm{i} \in\{1,2\}$, then function $\mathrm{F}\left(\mathrm{P}_{1}, \mathrm{P}_{2}\right)$ is supermodular and $\mathrm{P}_{1}$ and $\mathrm{P}_{2}$ are complementary policies only if:

$$
F(1,1)-F(0.1) \geq F(1,0)-F(0,0)
$$

Inequality (5) indicates that the implementation of a policy while another policy is being executed has a greater incremental impact on the performance of function $(F)$ than if this policy is executed in isolation. That is, the added value from the combination of two complementary policies exceeds the value that would be generated from the isolated application of these policies (Ennen \& Richter, 2010).

Therefore, we are interested in testing whether technology and experience are complementary variables in the context of the Spanish economy, i.e. if their simultaneous action generates higher productivity than that derived from the sum of the implementation of each of these two policies independently.

\section{Contextual variables and complementarity}

In the field of chemical science, there are substances or conditions whose presence stimulates and enables other chemicals to react with each other, leading to the formation of new chemical compounds. If these substances and conditions are not present, the chemical reaction does not take place. These substances that facilitate, accelerate and stimulate the processes of chemical reaction between different chemical elements are called catalysts.

In a sense, this is similar to the simultaneous performance of two or more activities or policies within a company: their implementation does not occur in a neutral or fully controlled atmosphere, but are rather simultaneously implemented alongside other policies. In other words, the presence of these other policies may influence the implementation and complementarity of the new policies. Therefore, we attempt to analyse the complementarity of variables not in isolation, but in light of existing relevant contextual variables.

Since we are interested in analysing the existence of complementarity between technological innovation and the growth rate of cumulative production, and use firm productivity as performance indicator, it seems appropriate to use as context variables the competitive atmosphere where firms perform and their ability to exploit economies of scale. We will use these two variables in view of their importance in the evolution of so-called economies of experience.

Companies that operate and prosper in competitive atmospheres have better opportunities to achieve greater market share. According to forecasts from the experience curve, this context enables them to increase their cumulative production, and consequently to increase their productivity levels. In this case, we use the potential size of the market in which the company operates as a proxy variable of the competitive atmosphere, considering the effect on the domestic market and the international one in a not exclusively way. Therefore, we assume that firms that only work in local markets are subject to less competitive tension, and thus have, by definition, a smaller market share. Obviously, we expect companies that work in large markets to have a more significant influence on productivity (Bernard \& Jensen, 1999; Sissoko, 2013).

On the other hand, larger companies have greater opportunities to exploit economies of scale, and thus a greater ability to transform production increases into corresponding reductions in unit costs, since they tend to use more efficient technologies (experience curve steeper) and increase their experience at a higher rate as a result of increased market share (Dixit, 1980; Schoeffler et al., 1974; Jovanovic, 1982). Consequently, we use firm size as a proxy for economies of scale in our empirical analysis, and we therefore expect that larger companies have a greater productivity than smaller ones. 


\section{Data, variables and methodology}

The data we use is taken from the Business Environment and Enterprise Performance Survey (BEEPS) of the European Bank for Reconstruction and Development (EBRD) and the World Bank Group. The survey was conducted between June and September 2005. The sample includes firms belonging to the manufacturing sector and the service sector, and excludes companies operating in sectors subject to supervision or government regulation, such as banking firms, power companies, railway transport companies, etc. Regarding Spain, the sample initially consisted of 606 companies. After debugging the sample, and as a result of lost values in the variables of interest, we ended up with a final sample of 519 companies.

The measure of business productivity that we use is labour force, i.e. annual sales per worker (labour productivity). In our study, we use the logarithm of labour productivity (LOGPROD) as the dependent variable.

With regards to technological innovation, we used three different dichotomous variables ( 0 , no; 1 yes). Companies were asked if they had successfully developed new products or services in the last 36 months (RADINN), and whether they had improved their existing products or services (INCRINN). The answers to these two questions allowed us to relate the output of innovation activities (radical innovation and incremental innovation) with productivity. Thus we intend to analyse the impact of these two kinds of innovation on firms' productivity. ${ }^{2}$

In addition, companies were asked whether they had acquired new production technology (in the form of machinery or equipment) in the last 36 months (ADQTECN). This variable will allow us to relate the acquisition of knowledge embodied in machinery and equipment with the productivity of companies. In this regard, it is surprising that much of the empirical literature on innovation has paid little attention to this form of acquisition of technological knowledge, given that this is the most used method by companies in traditional sectors. In fact, these companies are predominantly in countries relatively far from the corresponding technological frontier, as is the case with Spain. Pavitt (1984) noted that the main sources of innovation in many traditional manufacturing sectors are the suppliers of machinery and equipment.

According to the fundamentals of the experience curve, the growth rate of cumulative production $(\rho)$ influences firms' productivity. However, the available databases with technological information do not collect this variable. However, companies in the BEEPS are asked: "What was the capacity utilisation of facilities 36 months ago, and which is the capacity utilization now?" These questions allow us to ascertain whether companies have decreased, increased or kept intact its corresponding productive capacity, and

\footnotetext{
${ }^{2}$ Most studies that examine the innovation-productivity relationship at the firm level use R\&D expenditure as a proxy for innovation. Far fewer studies use a measure of innovation output (patents, product innovation, process innovation, etc.) as a proxy variable. Hall (2011)
}

therefore whether these companies have increased their cumulative production at a faster rate. Therefore, there is a clear relationship between the capacity utilization of facilities and productivity (Mohnen \& Hall, 2013). This allows us to construct three dummy variables: firms that increase their productive capacity (CAPPOSIT); firms that reduce their productive capacity (CAPNEG); and companies that maintain the same capacity (EQUCAP), which will be used as the reference variable. We expect that CAPPOSIT to have a positive influence on productivity, while CAPNEG should have a negative influence. We use dummy variables because this kind of variable is necessary to perform the test of complementarity.

We noted earlier that we are interested in performing a test of complementarity with the presence of other variables that incorporate competitive atmosphere and the ability of firms to exploit economies of scale. Many studies indicate that the larger and more diverse the demand a firm faces, the greater competitive pressure they will have to endure (Foster et al., 2008), suggesting there is a relationship between exports and productivity (Cassiman et al., 2010). Therefore, we will use whether the firm competes in the entire national market $(0$, no; 1 , yes) (DOMMARK) and the percentage of exports in a company's turnover (EXPORT) as context variables.

Regarding the ability to exploit economies of scale, we use firm size as a proxy variable. However, the size variable (SIZE) that we use is not absolute but relative; that is, the cutoff between larger (1) and smaller (0) companies is the average number of employees which prevails in each sector, because the potential to exploit economies of scale is different for each sector of the economy.

Finally, in order to compare the contribution of the industrial sector and the service sector to labour productivity, we define the dummy variable SECTOR, in which industrial companies take the value 0 and service companies take the value 1 .

We will use four different models in the empirical part of this paper. We will use a linear regression as an econometric technique in each of them, in which the dependent variable is the logarithm of labour productivity (LOGPROD). In model 1 , we will use as independent variables all the remaining variables referenced above. The significance of the coefficients of these variables allows us to gauge whether the different technological modalities considered (RADINN, INCRINN, ADQTECN) and the productive capacity (CAPPOSIT, CAPNEG) have any influence on labour productivity. It will also allow us to obtain information on the influence of contextual variables (DOMMARK, EXPORT, SIZE) and the SECTOR variable.

With the other models (2, 3 and 4 ), we will evaluate the complementarity between the following pairs of variables:

provides a sample of studies on productivity and innovation, and concludes that product innovations have a clear positive impact on productivity, while the role played by process innovations is ambiguous. 
(CAPPOSIT, RADINN) (CAPPOSIT, INCRINN) and (CAPPOSIT, ADQTEC).

The test of complementarity requires the use of a production function whereby the dependent variable must reflect a performance measure of the company (in our case, LOGPROD). The independent variables are the same as the ones used in model 1. However, according to the methodology of the test of complementarity, each pair of variables whose complementarity is to be analysed must be decomposed into four exclusive dummy variables, so that they are identical to the inequality (5). Obviously, in order to avoid perfect collinearity, models 2, 3 and 4 won't have constant.

As the analysis of complementarity is related to the implementation of a one-sided test, the econometric strategy that we employ will be as follows:

1. First, we contrast expression (5) using only the equality between both sides of the expression; that is, we will execute a two-sided test. If the null hypothesis is not rejected, it will not be necessary to make further contrasts, and we would conclude that the two variables analysed are not complementary. Thus, the two variables are independent.

2. However, if in the previous test the null hypothesis is rejected, we must perform a one-sided test in order to check if the variables are complementary or substitutive.

We will use the same econometric strategy whenever we conduct a one-sided test (first by testing the equality, and then, if necessary, the inequality).

\section{Results and discussion}

From the mean value of the LOGPROD variable we can classify the sample firms into two categories: those that have a lower than average productivity, and those that have a higher than average productivity. Table 1 shows the mean and standard deviation of each of the independent variables for each of the two categories of labour productivity.

In Table 1 we find that, with some exceptions, the high productivity subsample exhibits a higher mean value for the different variables than the low productivity subsample. For example, in the high productivity subsample, $36.36 \%$ of companies carry out radical innovations, while only $21.53 \%$ do so in the other subsample. The same happens with incremental innovation (40.26\% versus $24.31 \%$ ). However, with the acquisition of knowledge, embodied in new machinery and equipment, the opposite case occurs: $29.86 \%$ of low productivity firms use this type of knowledge, while only $21.21 \%$ of high productivity firms rely on this kind of technological innovation. Waiting for the econometric estimates to support this claim, it appears that the radical innovation and incremental innovation contribute to increasing firms' productivity, while the purchase of machinery and equipment seems to have a negative influence.

\section{Table 1: Descriptive statistics for productivity levels}

\begin{tabular}{l|c|c|c|c}
\hline \multirow{2}{*}{ Variables } & \multicolumn{2}{|c|}{$\begin{array}{c}\text { LOW } \\
\text { PRODUCTIVITY } \\
(288 \text { firms })\end{array}$} & \multicolumn{2}{c}{$\begin{array}{c}\text { HIGH } \\
\text { PRODUCTIVITY } \\
(231 \text { firms })\end{array}$} \\
\cline { 2 - 5 } & Mean & $\begin{array}{c}\text { Estandar } \\
\text { Deviation }\end{array}$ & Mean & $\begin{array}{c}\text { Estandar } \\
\text { Deviation }\end{array}$ \\
\hline RADINN & 0,2153 & 0,4117 & 0,3636 & 0,4821 \\
\hline INCRINN & 0,2431 & 0,4297 & 0,4026 & 0,4915 \\
\hline ADQTECN & 0,2986 & 0,4585 & 0,2121 & 0,4097 \\
\hline CAPPOSIT & 0,1076 & 0,3105 & 0,2468 & 0,4321 \\
\hline CAPNEG & 0,1042 & 0,3060 & 0,0693 & 0,2545 \\
\hline EQUCAP & 0,7882 & 0,4093 & 0,6840 & 0,4659 \\
\hline DOMMARK & 0,5347 & 0,4997 & 0,7143 & 0,4527 \\
\hline EXPORT & 0,0198 & 0,0916 & 0,0912 & 0,2098 \\
\hline SIZE & 0,0938 & 0,2920 & 0,3030 & 0,4606 \\
\hline SECTOR & 0,6424 & 0,4801 & 0,5887 & 0,4931 \\
\hline
\end{tabular}

In relation to the average values of the variables related to the utilization of production capacity, the values obtained are as expected: increases in production capacity appear to have a positive influence on firms' productivity, since $24.68 \%$ of high productivity companies increased their production capacity, while only $10.76 \%$ of companies in the lowproductivity subsample increased their production capacity. The relationship is reversed when companies reduce or maintain their productive capacity; in that case, the lowproductivity subsample is the group that contains higher average values. These figures provide evidence that variations in the utilization of production capacity can influence the labour productivity of enterprises.

The mean values of the variables related to the competitive atmosphere (DOMMARK and EXPORT) and the ability to exploit economies of scale (SIZE) are also as expected: these averages are higher in the high-productivity subsample, especially in terms of the SIZE variable.

Finally, we note that service companies are more abundant in the low-productivity subsample $(64.24 \%)$ than in the highproductivity one $(58.87 \%)$. 
Table 2: Outputs of the regressions

\begin{tabular}{|c|c|c|c|c|}
\hline & Model 1 & Model 2 & Model 3 & Model 4 \\
\hline RADINN & $\begin{array}{l}0.0821 * * \\
(0.0389)\end{array}$ & - & $\begin{array}{l}0.0813 * * \\
(0.0390)\end{array}$ & $\begin{array}{l}0.0843 * * \\
(0.0391)\end{array}$ \\
\hline INCRINN & $\begin{array}{c}0.0151 \\
(0.0387)\end{array}$ & $\begin{array}{c}0.0152 \\
(0.0387)\end{array}$ & - & $\begin{array}{c}0.0151 \\
(0.0387)\end{array}$ \\
\hline ADQTECN & $\begin{array}{l}-0.1212 * * * \\
(0.0363)\end{array}$ & $\begin{array}{l}-0.1208 * * * \\
(0.0364)\end{array}$ & $\begin{array}{l}-0.1207 * * * \\
(0.0363)\end{array}$ & - \\
\hline CAPPOSIT & $\begin{array}{c}0.0810^{*} \\
(0.0434) \\
\end{array}$ & - & - & - \\
\hline CAPNEG & $\begin{array}{l}-0.0759 \\
(0.0557) \\
\end{array}$ & $\begin{array}{l}-0.0765 \\
(0.0558) \\
\end{array}$ & $\begin{array}{l}-0.0738 \\
(0.0558) \\
\end{array}$ & $\begin{array}{l}-0.0766 \\
(0.0557) \\
\end{array}$ \\
\hline DOMMARK & $\begin{array}{l}0.1063 * * * \\
(0.0346)\end{array}$ & $\begin{array}{l}0.1061 * * * \\
(0.0346)\end{array}$ & $\begin{array}{l}0.1062 * * * \\
(0.0346)\end{array}$ & $\begin{array}{l}0.1053 * * * \\
(0.0346)\end{array}$ \\
\hline EXPORT & $\begin{array}{c}0.1789 * \\
(0.1041)\end{array}$ & $\begin{array}{c}0.1795^{*} \\
(0.1042)\end{array}$ & $\begin{array}{c}0.1771 * \\
(0.1042)\end{array}$ & $\begin{array}{c}0.1772 * \\
(0.1042)\end{array}$ \\
\hline SIZE & $\begin{array}{l}0.1633 * * * \\
(0.0432)\end{array}$ & $\begin{array}{l}0.1626 * * * \\
(0.0433)\end{array}$ & $\begin{array}{l}0.1673 * * * \\
(0.0435)\end{array}$ & $\begin{array}{l}0.1622 * * * \\
(0.0432)\end{array}$ \\
\hline SECTOR & $\begin{array}{c}0.0355 \\
(0.0323) \\
\end{array}$ & $\begin{array}{c}0.0360 \\
(0.0324) \\
\end{array}$ & $\begin{array}{c}0.0352 \\
(0.0324) \\
\end{array}$ & $\begin{array}{c}0.0355 \\
(0.0324) \\
\end{array}$ \\
\hline CAPPOSIT*RADINN (l 1 1) & - & $\begin{array}{l}1,9874 * * * \\
(0.0659)\end{array}$ & - & - \\
\hline 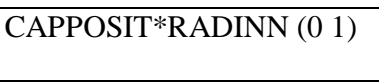 & - & $\begin{array}{l}1,9172 * * * \\
(0.0525)\end{array}$ & - & - \\
\hline CAPPOSIT*RADINN (1 0$)$ & - & $\begin{array}{l}1,9199 * * * \\
(0.0578)\end{array}$ & - & - \\
\hline CAPPOSIT*RADINN (l 0 0) & - & $\begin{array}{l}1,8308 * * * \\
(0.0364)\end{array}$ & - & - \\
\hline CAPPOSIT*INCRINN ( 11 1) & - & - & $\begin{array}{l}1.9544 * * * \\
(0.0671)\end{array}$ & - \\
\hline CAPPOSIT*INCRINN (0 1) & - & - & $\begin{array}{l}1.8363 * * * \\
(0.0548)\end{array}$ & - \\
\hline CAPPOSIT*INCRINN (1 0 ) & - & - & $\begin{array}{l}1.8861 * * * \\
(0.0592)\end{array}$ & - \\
\hline CAPPOSIT*INCRINN (0 0) & - & - & $\begin{array}{l}1.8354 * * * \\
(0.0363) \\
\end{array}$ & - \\
\hline CAPPOSIT*ADQTEC $\left(\begin{array}{ll}1 & 1\end{array}\right)$ & - & - & - & $\begin{array}{l}1.7553 * * * \\
(0.0875)\end{array}$ \\
\hline CAPPOSIT*ADQTEC ( $\left.\begin{array}{ll}0 & 1\end{array}\right)$ & - & - & - & $\begin{array}{l}1.7174 * * * \\
(0.0483)\end{array}$ \\
\hline CAPPOSIT*ADQTEC $\left(\begin{array}{ll}1 & 0\end{array}\right)$ & - & - & - & $\begin{array}{l}1.9237 * * * \\
(0.0522)\end{array}$ \\
\hline CAPPOSIT*ADQTEC ( $\left.\begin{array}{ll}0 & 0\end{array}\right)$ & - & - & - & $\begin{array}{l}1.8302 * * * \\
(0.0362)\end{array}$ \\
\hline CONSTANT & $\begin{array}{l}1.8319 * * * \\
(0.0360)\end{array}$ & - & - & - \\
\hline $\begin{array}{l}\text { Complementarity test: } \\
F(11)-F(01)=F(10)-F(0,0)\end{array}$ & & $\begin{array}{l}F(1,508)=0.05 \\
\text { p-value }=0.824\end{array}$ & $\begin{array}{l}\mathrm{F}(1,508)=0.63 \\
\text { p-value }=0,426\end{array}$ & $\begin{aligned} F(1,508)=0,32 \\
\text { p-value }=0.571\end{aligned}$ \\
\hline Model & $\mathrm{F}(9,509)=8.01 * * *$ & $\begin{array}{l}\mathrm{F}(11,508)= \\
1483.00 * * *\end{array}$ & $\begin{array}{l}\mathrm{F}(11,508)= \\
1484,76 * * *\end{array}$ & $\begin{array}{l}\mathrm{F}(11,508)= \\
1483.82 * * *\end{array}$ \\
\hline
\end{tabular}

Statistical significance of the coefficients: at $1 \%$ ***, $5 \% * *$ and $10 \% *$

According to the results of model 1 in Table 2, radical innovation positively and significantly influences the labour productivity of enterprises, while incremental innovation has no significant influence. Both results are consistent with the findings that different empirical studies have found relating to product innovation and process innovation in the economies of other countries (Hall, 2011). Moreover, the acquisition of embodied technology in machinery and equipment has a significant impact on labour productivity, although this is negative. It is revealing to note that this form of incorporation of technological knowledge is the most commonly used by Spanish companies (29.86\%), although its influence is negative. A study of Guisado-González et al. (2013) in the context of the Spanish hospitality sector had already found similar evidence using the Community Innovation Survey 2000 (CIS 2000) database. Results from model 1 reveal that a strategy of radical innovation has a greater impact on productivity, and that Spanish companies should rely less on the purchase of machinery and equipment as their main source of innovation. 
In regard to the productive capacity of firms, we find that an increase here has a significant positive influence on the productivity of Spanish firms, while a decrease has a negative influence, although this is not statistically significant. These results corroborate the forecasts of the experience curve.

In relation to the contextual variables, we find that the competitive atmosphere, both nationally and internationally, positively and significantly influences the productivity of firms, and that size has a positive and significant influence as an indicator of the ability of firms to exploit economies of scale.

Finally, the results reveal no significant differences between industrial and service companies in terms of their influence on the productivity of firms.

We use the output of models 2, 3 and 4 to assess the complementarity of the pairs of variables (CAPPOSIT, RADINN) (CAPPOSIT, INCRINN) and (CAPPOSIT, ADQTEC), respectively. Through implementing two-sided tests, we found that the variables that compose each of the pairs are independent of each other, since the respective pvalue of the complementary tests indicates that the corresponding null hypothesis should not be rejected. Therefore, we find that, in the context of the Spanish economy in the period analysed, technological innovation and increased production capacity are not complementary variables. Although in individual or joint action terms its influence on productivity can, in certain cases, be positive, the interaction is not complementary, i.e. simultaneous action does not produce synergistic effects on the productivity of Spanish companies.

Finally, although innovation and productive capacity are not complementary, we are interested in analysing the sign and significance of their joint action on productivity (Table 3 ). In this regard, we find that the joint action of radical innovation and an increase in productive capacity has a significant positive influence on the productivity of firms, since both the two-sided tests and the one-sided tests are rejected. In this case, the statistical significance level reaches $1 \%$. The joint action of incremental innovation and an increase in production capacity also has a positive influence, although the significance level is weaker (5\%). In this case, it is clear that the statistical influence stems mainly from an increase in production capacity, since we found in model 1 that the individual influence of incremental innovation was not statistically significant. Finally, the joint action of the purchase of machinery and equipment and the increase of production capacity has no significant influence on productivity, since the null hypothesis of two-sided tests is not rejected.
Table 3: Hypothesis tests of some coefficients of model 1

\begin{tabular}{|c|c|c|}
\hline Hypotheses test & Test values & Interpretation \\
\hline $\begin{array}{l}\text { CAPPOSIT + } \\
\text { RADINN }=0\end{array}$ & $\begin{array}{c}\mathrm{F}(1,509)=9.35 \\
\mathrm{p} \text {-value }= \\
0.0023\end{array}$ & $\begin{array}{l}\text { Reject the } \\
\text { hypothesis at a } \\
\text { statistical } \\
\text { significance level of } \\
1 \%\end{array}$ \\
\hline $\begin{array}{l}\text { CAPPOSIT + } \\
\text { RADINN } \leq 0\end{array}$ & $\begin{array}{c}\mathrm{F}(1,509)=9.35 \\
\mathrm{p} \text {-value }= \\
0.0011\end{array}$ & $\begin{array}{l}\text { Reject the } \\
\text { hypothesis at a } \\
\text { statistical } \\
\text { significance level of } \\
1 \%\end{array}$ \\
\hline $\begin{array}{l}\text { CAPPOSIT + } \\
\text { INCRINN }=0\end{array}$ & $\begin{array}{c}\mathrm{F}(1,509)=3.19 \\
\mathrm{p} \text {-value }= \\
0.0749\end{array}$ & $\begin{array}{l}\text { Reject the } \\
\text { hypothesis at a } \\
\text { statistical } \\
\text { significance level of } \\
10 \%\end{array}$ \\
\hline $\begin{array}{l}\text { CAPPOSIT + } \\
\text { INCRINN } \leq 0\end{array}$ & $\begin{array}{c}\mathrm{F}(1,509)=3.19 \\
\mathrm{p} \text {-value }= \\
0.0374\end{array}$ & $\begin{array}{l}\text { Reject the } \\
\text { hypothesis at a } \\
\text { statistical } \\
\text { significance level of } \\
5 \%\end{array}$ \\
\hline $\begin{array}{l}\text { CAPPOSIT + } \\
\text { ADQTEC }=0\end{array}$ & $\begin{array}{c}\mathrm{F}(1,509)=0.47 \\
\mathrm{p} \text {-value }= \\
0.4950\end{array}$ & $\begin{array}{l}\text { Hypothesis is not } \\
\text { rejected }\end{array}$ \\
\hline
\end{tabular}

To summarize, we note that the pairs of variables analysed are not complementary, i.e. the influence on firms' productivity, which stems from their simultaneous implementation, is not superior to the one obtained from the sum of its independent implementation. However, the joint action of radical innovation and an increase in productive capacity, on the one hand, and incremental innovation and the increase in production capacity, on the other, have a significant positive influence on firms' productivity. This is not true with the acquisition of machinery and equipment and an increase in productive capacity, since their joint action is not significant. Once again, we find that the acquisition of machinery and equipment leads to undesirable results, because its implementation could nullify the positive influence of one of the main sources of productivity in Spanish firms: an increase in productive capacity.

In sum, innovation and an increase in productive capacity generally influence business productivity positively and significantly, as predicted by the fundamentals of the experience curve. In the context of the Spanish economy, the most remarkable influence is radical technological innovation, although the domestic market and the size of the companies both have a very remarkable and significant influence too.

\section{Conclusions}

The data used in the realization of this empirical study are related to the period 2002-2005, a period in which most companies in the Spanish economy experienced strong growth. In this regard, the results reveal that the domestic economy is a variable with strong explanatory power for increases in firms' productivity. Exports have a much smaller role, which is a clear indication of the international competitive weakness of a large number of Spanish firms. 
Both factors suggest that Spanish firms are extremely dependent on the development of their domestic economy.

Moreover, it is known that the Spanish economy is characterized, in general, by having a medium level of technological innovation, as well as being strongly dependent on the purchase of machinery and equipment that incorporates traditional technology. That issue allows us to understand the weak international competitiveness of Spanish companies, which are strongly dependent on the existence of low wage levels. In this regard, the output of the study reveals that neither incremental innovation nor the purchase of machinery and equipment have a significant positive influence on the productivity of Spanish companies. Furthermore, the purchase of machinery and equipment that incorporates technological innovation has a negative and highly significant influence on productivity. Therefore, it appears that the productivity gains of the period analysed have depended crucially on the expansive phase of the Spanish economy and, to some extent, on the companies that have undertaken radical innovations.

It can therefore be inferred that once the growth cycle of the Spanish economy has been depleted, it will be necessary to modify the corresponding productive patterns. This will involve encouraging innovative activities of a radical and incremental nature and decreasing the historical dependence of the Spanish productive system on the purchase of machinery and equipment that incorporates traditional technology.

Indeed, this empirical study reveals that the joint action of the growth cycle and technology has not led to the generation of synergies or complementarities. One possible reason is that traditional technology is not able to exploit the full potential that an expansive cycle entails, as can be seen in the hypothesis we tested in Table 3. In order to check if technology and growth cycles produce complementary effects on company productivity, it would be desirable to perform a similar study in other more technologically advanced countries.

To summarize, we conclude by noting that, in general, this empirical study supports the principles of the experience curve, since both technology and an increase in productive capacity positively and significantly influenced firms' productivity. Nevertheless, in the context of the Spanish economy, it has not been possible to verify that the two variables are complementary. In other words, we have not confirmed the miracle of the multiplication of the loaves and fishes.

\section{References}

Adegbesan, J. 2009. 'On the origins of competitive advantage: Strategic factor markets and heterogeneous resource complementarity', Academy of Management Review, 34: 463-475.

Barney, J.B. 1991. 'Firm resources and sustained competitive advantage', Journal of Management, 17(1): 99-120.
Bernard, A.B. \& Jensen, B.J. 1999. 'Exceptional exporter performance: Cause, effect or both?', Journal of International Economics, 47: 1-25.

Bertrand, J. 1883. 'Review of 'théorie mathématique de la richesse sociale' and 'recherche sur les principles mathématiques de la théorie des richesses', Journal de Savants, 48: 499-508.

Birch, D. 1979. The job generation process. Unpublished manuscript. Cambridge, MA: MIT Program on Neighborhood and Regional Change.

Cassiman, B. \& Veugelers, R. 2006. 'In search of complementarity in innovation strategy: Internal $R \& D$ and external knowledge acquisition', Management Science, 52(1): 68-82.

Cassiman, B., Golovko, E. \& Martínez-Ros, E. 2010 'Innovation, exports and productivity', International Journal of Industrial Organization, 28: 372-376.

Cohen, W.M. \& Levinthal, D.A. 1989. 'Innovation and learning: The two faces of R\&D', Economic Journal, 99: 569-596.

Cohen, W.M. \& Levinthal, D.A. 1990. 'Absorptive capacity: A new perspective on learning and innovation', Administrative Science Quarterly, 35(1): 128-152.

Conner, K. 1991. 'A historical comparison of resource-based theory and five schools of thought within industrial organization economics: Do we have a new theory of the firm', Journal of Management, 17(1): 121-154.

Cournot, A. 1838. Recherches sur les príncipes mathématiques de la théorie des richesses. Chez L. Hachette, Libraire de l'Université Royale de France, Paris.

Day, G.S. \& Montgomery, D.B. 1983. 'Diagnosing the experience curve', Journal of Marketing, 47: 44-58.

Dixit, A. 1980. 'The role of investment in entry deterrence', Economic Journal, 90: 95-106.

Edgeworth, F. 1881: Mathematical psychics: An essay on the application of mathematics to the moral sciences. Reprints of Economic Classic, Augustus M. Kelley Publishers, New York.

Edgeworth, F. 1925. 'The pure theory of Monopoly. In F. Edgeworth (1925): Papers relating to political Economy, Mcmillan, Londres, Volumen 1, 111-142.

Ennen, E. \& Richter, A. 2010. 'The whole is more the sum of its parts - or is it? A review of the empirical literature on complementarities in organizations', Journal of Management, 36(1): 207-233.

Foster, L., Haltiwanger, J., Syverson, C. 2008. 'Reallocation, firm turnover, and efficiency: selection on productivity or profitability?', American Economic Review, 98(1): 394-425.

Freeman, C. 1991. 'Networks of innovators: A synthesis of research issues', Research Policy, 20(5): 499-514.

Griliches, Z. 1979 'Issues in assessing the contribution of research and development to productivity growth', Bell Journal of Economics, 10: 92-116. 
Griliches, Z. 1986. 'Productivity, R\&D and basic research at the firm level in the 1970's', American Economic Association, 76: 141154.

Hall, B.H., 2011. 'Innovation and productivity', Nordic Economic Policy Review, 2: 167-204.

Harhoff, D. 1998. 'R\&D and productivity in German manufacturing firms', Economics of Innovation and New Technology, 6: 29-50.

Jaumandreu, J. 2009. What explains the evolution of productivity and competitiveness? The innovation link, Working Paper No 804, IESE Business School, University of Navarra.

Jovanovic, B. 1982. 'Selection and the evolution of industry', Econometrica, 50(3): 649-670.

Lieberman, M.B. 1981. The experience curve, pricing and market structure in the chemical processing industries, Unpublished working paper, Harvard University (December 15).

Lieberman, M.B. \& Montgomery, D.D. 1988. 'First mover advantages', Strategic Management Journal, 9(Issue Special)" 4158 .

Lotti, F. \& Santarelli, E. 2001. 'Linking knowledge to productivity: A Germany-Italy comparison using the CIS database', Empirica, 28: 293-317.

Mairesse, J. \& Sassenou, M. 1991. R\&D and productivity: A survey of econometric studies at the firm level, Working Paper No 3666, NBER, Cambridge, MA.

Milgrom, P. \& Roberts, J. 1990. 'The economics of modern manufacturing: Technology, strategy, and organization', American Economic Review, 80: 511-528.

Miller, D. \& Friesen, P.H. 1984. 'A longitudinal study of the corporate life cycle’, Management Science, 30: 1161-1183.

Miller, D. 1986. 'Configurations of strategy and structure: Towards a synthesis', Strategic Management Journal, 7: 233-249.

Mohnen, P. \& Hall, B.H. 2013. 'Innovation and productivity: An update', Eurasian Business Review, 3(1): 47-65.

Parisi, M.L., Schiantarelli, F. \& Sembenelli, A. 2006. 'Productivity, innovation and R\&D: micro evidence for Italy', European Economic Review, 50: 2037-2061.

Pavitt, K. 1984. 'Sectoral patterns of technical change', Research Policy, 13: 343-373

Peteraf, M.A. 1993. 'The cornerstones of competitive advantage: A resource-based view', Strategic Management Journal, 14: 170-181.

Petersen, D.R. \& Ahmad, N. 2007. High-Growth Enterprises and Gazelles: Preliminary and Summary Sensitivity Analysis. OECD, Paris.

Powell, T.C. \& Dent-Micallef, A. 1997. 'Information technology as competitive advantage: The role of human, business, and technology resources', Strategic Management Journal, 18: 375-405.

Rosenberg, N. 1990. 'Why do firms do basic research (with their own money)?', Research Policy, 19: 165-174.
Rothwell, R., Freeman, C., Horsley, A., Jervis, V.T.P., Robertson, A.B. \& Townsend, J. 1974. 'Sappho updated: Project sappho: phase II', Research Policy, 3(3): 258-291.

Rothwell, R. 1975. 'Innovation and firm size: A case for dynamic complementarity; or, is small really so beautiful?', Journal of General Management, 2: 5-25.

Schoeffler, S., Buzzell, R. D. \& Heany, D.F. 1974. 'Impact of strategic planning on profit performance', Harvard Business Review, March-April: 137-145.

Sissoko, A. 2013. 'R\&D Subsidies and Firm-Level Productivity: Evidence from France', 2013, Discussion Paper 2011-2, Institut de Recherches Économiques et Sociales de l'Université Catholique de Louvain, Belgium.

Somaya, D., Williamson, I.O. \& Zhang, X. 2007. 'Combining patent law expertise with R\&D for patenting performance', Organization Science, 18: 922-937.

Stobaugh, R.B. \& Townsend, P.L. 1975. 'Price forecasting and strategic planning: The case of Petro Chemicals', Journal of Marketing Research, 12(February): 19-29.

Topkis, D.L. 1978. 'Minimizing a submodular function on a lattice', Operations Research, 26: 305-321.

Vives, X. 1990. 'Nash equilibrium with strategic complementarities', Journal of Mathematical Economics, 19(3): 305-321.

Wernerfelt, B. 1984. 'A resource-based view of the firm', Strategic Management Journal, 5(2): 171-180. 